\section{FIRST RECORD OF RATANAWORABHANS'S FRUIT BAt MEgaERops NIPHANAE YeNBUtRA \& Felten, 1983 (ChIROPTERA: Pteropodidae) FROM BANGLADESH}

\section{Mohammad Nurul Islam ${ }^{1}$, Amir Hossan Shaikat ${ }^{2}$, Kazi Muhammad Fakhrul Islam ${ }^{3}$, Subrata Kumar Shil ${ }^{4}$, Sazeda Akter ${ }^{5}$, Mohammad Mizanur Rahman ${ }^{6}$, Mohammad Mahmudul Hassan ${ }^{7}$, Ariful Islam ${ }^{8}$, Shahneaz Ali Khan ${ }^{9} \&$ Neil Furey ${ }^{10}$}

$1,2,3,4,5,6,7,9$ Faculty of Veterinary Medicine, Chittagong Veterinary and Animal Sciences University, Bangladesh

${ }^{8}$ EcoHealth Alliance, 460 West $34^{\text {th }}$ Street, $17^{\text {th }}$ Floor, New York, NY 10001-2320, USA

${ }^{10}$ Fauna \& Flora International, Cambodia Programme, PO Box 1380 \#19, Street 360, Boeng Keng Kong 1, Chamkarmon, Phnom Penh 12000, Cambodia

${ }^{1}$ nurul.dvm@gmail.com (corresponding author), ${ }^{2}$ dramir04@gmail. com, ${ }^{3}$ fakhruldvm15@gmail.com, ${ }^{4}$ skshilvet@yahoo.com,

${ }^{5}$ najatdvm@gmail.com, ${ }^{6}$ mizanurvet@gmail.com, ${ }^{7}$ miladhasan@ yahoo.com, ${ }^{8}$ arif@ecohealthalliance.org, ${ }^{9}$ shahneazbat@gmail.com, ${ }^{10}$ neil.furey@fauna-flora.org

The bat fauna of Bangladesh is poorly known. Previous checklists (Khan 1982; 2001) only included 31 bat species for the country and were more recently extended by
Srinivasulu \& Srinivasulu (2005) to 38 species. Given the lack of survey effort for bats however, this figure undoubtedly still falls short of the true total. For example, Srinivasulu \& Srinivasulu (2005) listed an additional 28 bat species

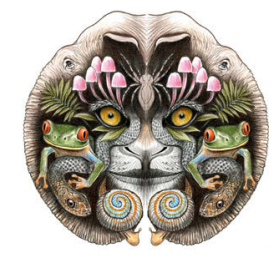

ISSN 0974-7907 (Online) ISSN 0974-7893 (Print)

\section{OPEN ACCESS} that are likely to be also occurring in the country and noted that at least 44 species occur in neighbouring territories (Meghalaya, Mizoram and Tripura) in northeastern India, and that Bangladesh's bat fauna is under represented due to lack of bat surveys.

In January 2014, a training event on bat research techniques and conservation was held at the Chittagong Veterinary \& Animal Sciences University (CVASU) in southeastern Bangladesh. As part of a field session undertaken during the event, a single bat was captured at the Bangladesh Agriculture Research Institute $\left(22.363185^{\circ} \mathrm{N} \& 91.804198^{\circ} \mathrm{E}\right)$ which lies adjacent to the university. Upon examination, it was determined that the external and craniodental characteristics of this animal did not correspond to any bat species previously recorded in the country. The purpose of this note is therefore to document the occurrence of this species as
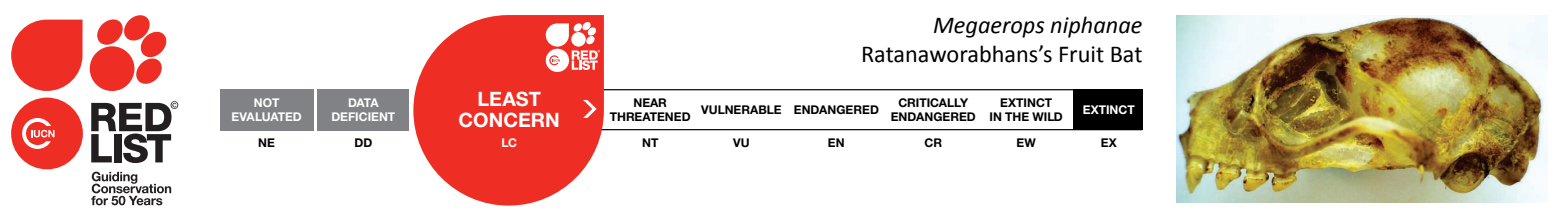

DOI: http://dx.doi.org/10.11609/JoTT.o4387.7821-4 | ZooBank: urn:Isid:zoobank.org:pub:8DD8F7C1-FC1F-42E9-9F92-B52019274A88

Editor: C. Srinivasulu, Osmania University, Hyderabad, India.

Date of publication: 26 September 2015 (online \& print)

Manuscript details: Ms \# 04387 | Received 19 August 2015 | Finally accepted 16 September 2015

Citation: Islam, M.N., A.H. Shaikat, K.M.F. Islam, S.K. Shil, S. Akter, M.M. Rahman, M.M. Hassan, A. Islam, S.A. Khan \& N. Furey (2015). First record of Ratanaworabhans's Fruit Bat Megaerops niphanae Yenbutra \& Felten, 1983 (Chiroptera: Pteropodidae) from Bangladesh. Journal of Threatened Taxa 7(11): 7821-7824; http:// dx.doi.org/10.11609/JoTT.04387.7821-4

Copyright: ( Islam et al. 2015. Creative Commons Attribution 4.0 International License. JoTT allows unrestricted use of this article in any medium, reproduction and distribution by providing adequate credit to the authors and the source of publication.

Funding: The article produced by two capacity building workshop in 2014 \& 2015, while first workshop was supported by Zoo Outreach Organization and $2^{\text {nd }}$ workshop is funded by Rufford Small Grants by The Rufford Foundation, UK (13131-1).

Conflict of Interest: The authors declare no competing interests.

Acknowledgements: The authors would like to thank Sally Walker of the Zoo Outreach Organisation, and Bat Conservation International for financially supporting the field activities that led to the present note and Md. Ahasanul Hoque of Chittagong Veterinary and Animal Sciences University for his steadfast support. We also thank the authorities of the Bangladesh Forest Department and Bangladesh Agricultural Research Institute for permitting the field research.
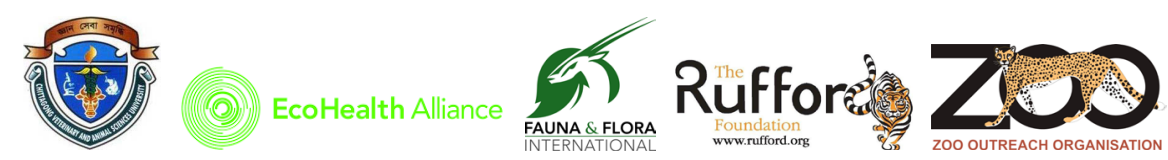
a new record for Bangladesh.

Materials and Methods: The specimen is deposited at the Chittagong Veterinary and Animal Sciences University (CVASU). Age and reproductive status were assessed following Racey (2009) and Brunet-Rossinni \& Wilkinson (2009). Photographs were unfortunately not taken of the specimen in life. External measurements were taken from the alcohol preserved specimen to the nearest $0.1 \mathrm{~mm}$, while craniodental measurements were taken to the nearest $0.01 \mathrm{~mm}$ using digital calipers under a stereo microscope. Definitions for external measurements were as follows: FA: forearm length from the extremity of the elbow to the extremity of the carpus with the wings folded; HB: head and body length - from the tip of the snout to the anal opening; $E$ : ear length - from the lower border of the external auditory meatus to the tip of the pinna, excluding any hair; TIB: tibia length - from the knee joint to the ankle; HF: hindfoot - from the tip of the longest digit, excluding the claw, to the extremity of the heel, behind the os calcis. Illustrations of these measurements are provided by Bates \& Harrison (1997).

Definitions for craniodental measurements were as follows: GTL: greatest length of skull - greatest anteroposterior diameter of the skull, taken from the most projecting point at each extremity along the median line of the skull; $C B L$ : condylobasal length - from the exoccipital condyle to the anterior rim of alveolus of the first upper incisor; CCL: condylo-canine length - from the exoccipital condyle to the most anterior part of the canine; ZYW: zygomatic width - the greatest width of the skull across the zygomatic arches; MAW: mastoid width - the greatest distance across the mastoid region; $\mathrm{CM}^{1} \mathrm{~L}$ : maxillary toothrow length - from the front of upper canine to the back of the crown of the third molar; $\mathrm{C}^{1} \mathrm{C}^{1} \mathrm{~W}$ : width across the upper canines - greatest width, taken across the outer borders of upper canines; $M^{1} M^{1} W$ : width across the upper molars - greatest width, taken across the outer crowns of the last upper molars; ML: mandible length - from the anterior rim of the alveolus of the first lower incisor to the most posterior part of the condyle; $\mathrm{CM}_{2} \mathrm{~L}$ : mandibular toothrow length - from the front of the lower canine to the back of the crown of the last lower molar; $\mathrm{CPH}$ : least height of the coronoid process - from the tip of the coronoid process to the apex of the indentation on the inferior surface of the ramus adjacent to the angular process. Nomenclature follows Simmons (2005).

Results: Material examined: CVASU0001, adult male, in spirit, skull removed, collected by M.N. Islam, A.H. Shaikat, K.M.F. Islam \& Neil Furey on 23.i.2014,

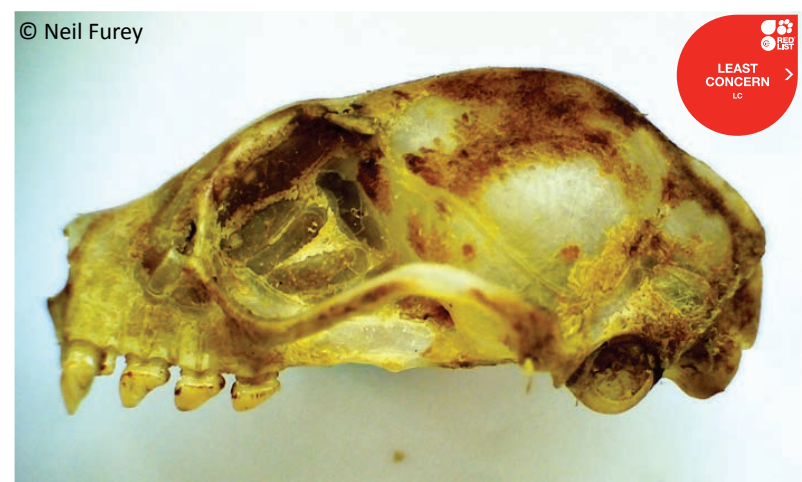

Image 1. Lateral view of the skull of Megaerops niphanae (CVASU0001) from Bangladesh.

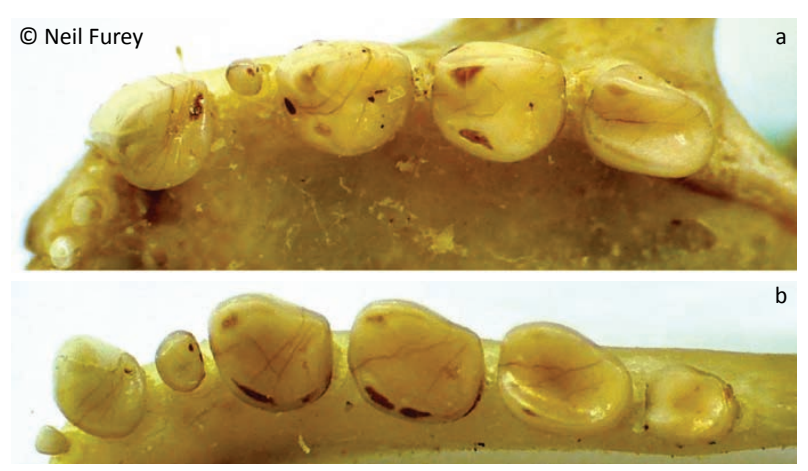

Image 2. Occlusal view of left upper (a) and right lower (b) dentition of Megaerops niphanae (CVASU0001) from Bangladesh.

Bangladesh Agriculture Research Institute, Chittagong, $22.363185^{\circ} \mathrm{N} \& 91.804198^{\circ} \mathrm{E}, 17 \mathrm{~m}$ elevation. The bat was caught in a mist net in early evening in an area of mixed orchard including guava, lychee, coconut, papaya, jackfruit and lemon.

External measurements were: $F A=58.3, H B=77.2$, $\mathrm{E}=16.0, \mathrm{TIB}=23.9$ and $\mathrm{HF}=10.6 \mathrm{~mm}$. Craniodental measurements were: $\mathrm{GTL}=28.39, \mathrm{CBL}=26.71, \mathrm{CCL}=$ 26.48, $\mathrm{ZYW}=18.77, \mathrm{MAW}=11.27, \mathrm{CM}^{1} \mathrm{~L}=8.74, \mathrm{C}^{1} \mathrm{C}^{1} \mathrm{~W}=$ 5.82, $\mathrm{M}^{1} \mathrm{M}^{1} \mathrm{~W}=8.66 ; \mathrm{ML}=20.9 ; \mathrm{CM}_{2} \mathrm{~L}=9.58, \mathrm{CPH}=11.83$ $\mathrm{mm}$.

The above specimen was referred to $M$. niphanae on the basis of the following characters: dorsal hair uniformly brownish-grey; ventral hair mid-grey with slightly darker flanks; ears simple with broadly rounded tips and dark margins; external tail absent; claw present on distal extremity of second digit; nostrils slightly tubular; external measurements in accordance with published ranges (Bates \& Harrison 1997; Hendrichsen et al. 2001; Francis 2008); rostrum squarish in outline and not elevated anteriorly (as in M. ecaudatus) (Image 1 ); dorsal profile of skull ascending to the midpoint of braincase before descending steeply to lambda; dental 
formula: 2/1 (incisors), 1/1 canines, 3/3 (premolars), $1 / 2$ (molars); first upper premolar $\left(P^{2}\right)$ minute, located within toothrow and only slightly larger than first upper incisor $\left(\mathrm{I}^{2}\right)$ in crown area; middle and last upper premolars $\left(\mathrm{P}^{3}, \mathrm{P}^{4}\right)$ robust with distinct antero-internal and antero-external cusps; single upper molar $\left(\mathrm{M}^{1}\right)$ also robust, though slightly smaller and more elongated than $\mathrm{P}^{4}$ (Image 2a); first lower premolar $\left(\mathrm{P}_{2}\right)$ small, though larger than $\mathrm{P}^{2}$; remaining lower premolars $\left(\mathrm{P}_{3}, \mathrm{P}_{4}\right)$ and first lower molar $\left(M_{1}\right)$ robust, whereas the second $\left(M_{2}\right)$ is distinctly smaller, occupying approximately less than half the crown area of $M_{1}$ (Image $2 b$ ).

Discussion: As Ratanaworabhans's Fruit Bat has been recorded over a wide range of elevations from neighbouring territories in India (Arunachal Pradesh, Manipur, Mizoram, Nagaland and West Bengal) (Molur et al. 2002), its discovery in Bangladesh is not surprising. Outside the country, the taxon is also found throughout much of Thailand, Laos, Cambodia and Vietnam where it has been recorded in a wide variety of forests and cultivated lands (Simmons 2005; Francis 2008; Kruskop 2013) (Image 3). Although not reported yet for Myanmar, its presence in the neighbouring area of Chittagong of southeastern Bangladesh also supports previous suggestions that the species likely occurs there (Francis 2008).

Ratanaworabhans's Fruit Bat has often been confused with Temminck's Tailless Fruit Bat M. ecaudatus in the past, with some records of the latter from India, Thailand and Vietnam subsequently assigned to $M$. niphanae by Corbet \& Hill (1992). While M. ecaudatus as presently recognised is distributed from southern
Thailand and Malaysia through to Indonesia, it has also been suggested that some records of $M$. niphanae from northeastern India may actually be referable to $M$. ecaudatus (Bates et al. 2008); this question has yet to be resolved.

Our incidental discovery of a new country record during a single evening of sampling in a heavily urbanised area highlights the current incompleteness of faunal knowledge and potential for future discoveries in Bangladesh. Much greater survey effort and sustained investments into developing taxonomic capacity and museum collections in the country are needed to realize this potential.

\section{References}

Brunet-Rossinni, A.K. \& G.S. Wilkinson (2009). Methods for age estimation and the study of senescence in bats, pp. 315-325. In: Kunz, T.H. \& S. Parsons (eds.). Ecological and Behavioral Methods for the Study of Bats - $2^{\text {nd }}$ Edition. Johns Hopkins University Press, Baltimore, xvii+901pp.

Bates, P.J.J. \& D.L. Harrison (1997). Bats of the Indian Subcontinent. Harrison Zoological Museum, Kent, United Kingdom, xvi+258pp.

Bates, P., S. Bumrungsri, A. Suyanto \& C. Francis (2008). Megaerops ecaudatus. The IUCN Red List of Threatened Species. Version 2014.3. <www.iucnredlist.org>. Downloaded 01 June 2015; http:// dx.doi.org/10.2305/IUCN.UK.2008.RLTS.T12946A3400872.en

Corbet, G.B. \& J.E. Hill (1992). The Mammals of the Indomalayan Region: A Systematic Review. Oxford University Press, Oxford, United Kingdom, 488pp.

Francis, C.M. (2008). A Guide to the Mammals of Southeast Asia. Princeton University Press, Princeton, New Jersey, 392pp.

Hendrichsen, D.K., P.J.J. Bates \& B. Hayes (2001). Recent records of bats (Chiroptera) from Cambodia. Acta Chiropterologica 31(1): 21-32.

Khan, M.A.R. (1982). Wildlife of Bangladesh - A Checklist. Dhaka University, Dhaka, iv+174pp.

Khan, M.A.R. (2001). Status and distribution of bats in Bangladesh

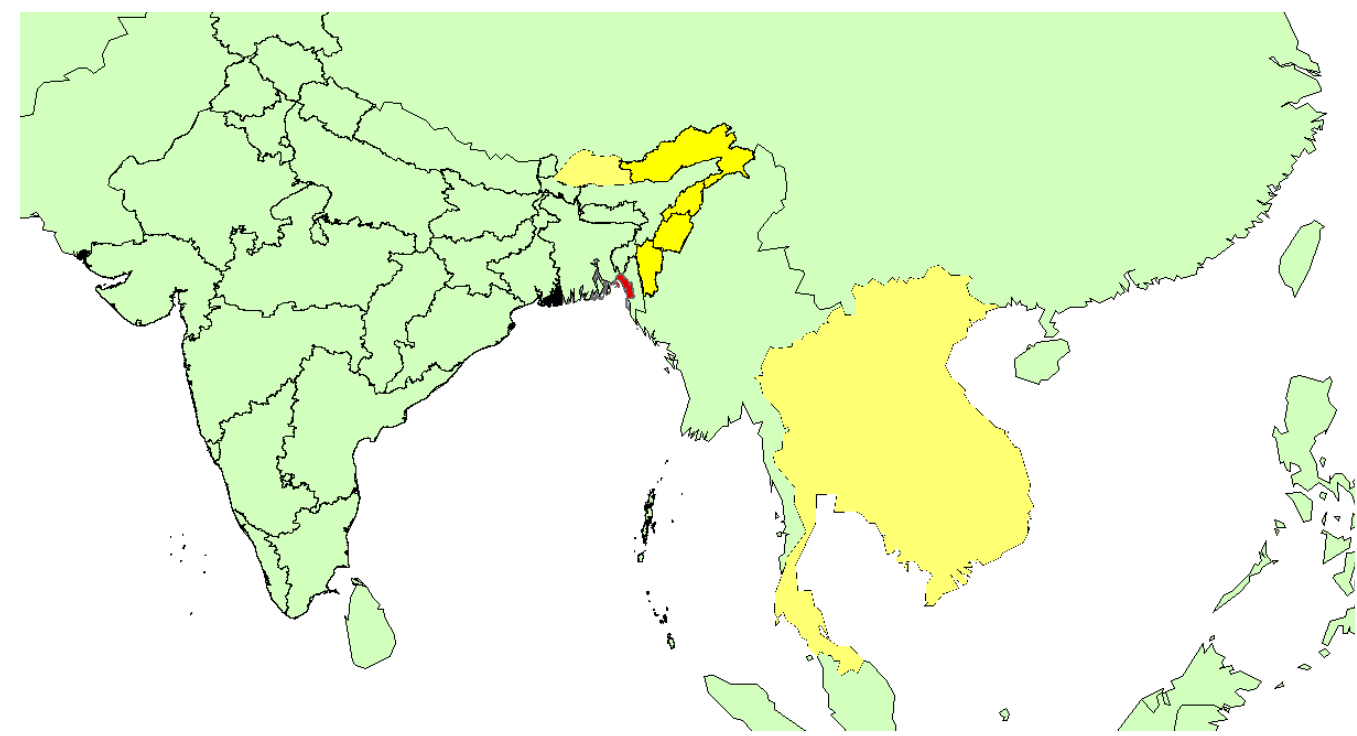

Image 3. Distribution of Megaerops niphanae (yellow shading indicates the known distribution and red shading the new locality of the species) 
with notes on their ecology. Zoos' Print Journal 16(5): 479-483; http://dx.doi.org/10.11609/JoTT.ZPJ.16.5.479-83

Kruskop S.V. (2013). Bats of Vietnam: Checklist and an Identification Manual. Joint Russian-Vietnamese Science and Technologica Tropical Centre, Zoological Museum of Moscow M.V. Lomonosov State University, Moscow, 316pp.

Molur, S., G. Marimuthu, C. Srinivasulu, S. Mistry, A.M. Hutson, P.J.J Bates, S. Walker, K. Padmapriya \& A.R. Binupriya (eds.) (2002). Status of South Asian Chiroptera: Conservation Assessment and Management Plan (C.A.M.P.) Workshop Report. Zoo Outreach Organisation, Conservation Breeding Specialist Group South Asia, and Wildlife Information \& Liaison Development Society, Coimbatore, India, viii+154pp+CD.
Racey, P.A. (2009). Reproductive assessment in bats, pp. 249-264. In: Kunz, T.H. \& S. Parsons (eds.). Ecological and Behavioral Methods for the Study of Bats - $2^{\text {nd }}$ Edition. Johns Hopkins University Press, Baltimore, xvii+901pp.

Simmons, N.B. (2005). Order Chiroptera, pp. 312-529. In: Wilson, D.E. \& D.M. Reeder (eds.). Mammal Species of the World: A Taxonomic and Geographic Reference - $3^{\text {rd }}$ Edition. Vol. 1. Johns Hopkins University Press, Baltimore, i-xxxv+1-743pp.

Srinivasulu, C. \& B. Srinivasulu (2005). A review of chiropteran diversity of Bangladesh. Bat Net - CCINSA Newsletter 6(2): 5-11.

Wiling 